\title{
Genetics Diversity and Agronomic Characters of F3 Lines Selected by Recurrent Selection for Drought Tolerance and Blast Resistance of Bengkulu Local Rice Varieties
}

\author{
Reny Herawati, Entang Inoriah", Rustikawati", Mukhtasar ${ }^{\#}$ \\ ${ }^{\#}$ Department of Agroecotecnology, University of Bengkulu, WR Supratman Street, Bengkulu, 38371A, Indonesia \\ E-mail: reny.herawati70@gmail.com
}

\begin{abstract}
Recurrent selection (RS) is a method of selection by crossing selected plants from systematic population to develop new superior population. The recurrent selection had been implemented in local varieties to produce drought tolerance and blast resistance of rice lines. This research was conducted at Experimental Station, Indonesian Center for Rice Research, Muara Bogor, West Java and Pondok Kelapa, Bengkulu, Indonesia. A number of F2 RS line used as based population and F3 populations had been identified. The potential of agronomic characteristics had produced some selected lines. There was an increase in the value of the average the number of filled grains/panicle which grain fertility was compared with its constituent elders. Selection based on plant height, the number of productive tillers, the number of grains per panicle, the number of filled grain per panicle and grain weight/hill will be effective in early generations because it had high heritability values and broad genetic diversities. Further evaluation of lines should be arranged on the specific environment in order to obtain superior lines as previously intended.
\end{abstract}

Keywords - Recurrent selection; genetic diversity; local rice; drought tolerance;blast resistance

\section{INTRODUCTION}

Rice breeding to get inbreds homogeneous needs to be selected to obtain information on the agronomic traits of high yielding lines, lines need to be planted again as plants observation and yield trials. Based on these experiences, should be developed further by way of exploring the local varieties are high yielding but does not have the properties of drought resistance and blast disease that often struck planting upland rice in Indonesia.

Local varieties had been used in the breeding program to improve genetic potential. Local varieties had been planted by farmers for many generations on the specific agroecological region so that presumably they are resistant/tolerant to biotic or abiotic stresses in a specific location. Use of local varieties as parental hybridization is recommended for getting superior specific genotype on the new varieties so that released varieties should have a broad genetic variability [1], [2], [3]. Specific local rice breeding in conventional methods in a dry land to improved high yielding couldn't do without known genetic problems and the way of heritability desiring. Populations have high genetic diversity will give a good response to selection for high genetic diversity will provide great opportunities to get the right cross combination with the superior combined properties. To achieve the purpose of the selection so that the selection of one or more characters can be made more effective should be known relationships between agronomic characters, yield and yield components [4], [5].

Conventional breeding method to improve high yielding specific local rice in the dry land needs proper knowledge about genetic problems and the way of heritability desired. The selection will give an optimum response if using true criteria. Methods of selection usually applied in rice breeding in Indonesia are pedigree, bulk and a modified bulk-pedigree [6]. These methods depend on the natural accumulation of desired characters from the parents into a plant/line [6]. The most effective breeding method to improve single-gene controlled characters is backcross, but to improve more than one of characters using recurrent selection method. Recurrent selection (RS) is a method of plant selection and crossing from systematic population to develop new superior population [7], [8]-[10]. On the other hand, this method is a powerful procedure to accumulate desirable genes from crossing recombination between continuously selected segregants to get the best new population than before, because it consists of plants that have a combination of traits is desired. The method has been 
done and succeeds in breeding some crops, such as corn and wheat [7], [11]. Reference [12] showed that recurrent selection applied to genetically divergent populations could result in considerable gains for grain yield, the gain observed in the second cycle and the mean gain observed due to the selection in the first and second cycles were significant.

Breeding technique in RS method has applied to the estimate of genetic progress after eight cycles for common bean grain yield [13], but still not effective in the selfpollinated plant like soybean [7]. RS have applied well in Brazilian upland rice breeding [10] and maize using the 11th cycle of reciprocal recurrent selection [4]. In soybean, RS can improve the yield of each cycle [7]. Reference [8] using both combinations between RS and anther culture to accelerate the development of new plant type variety of rice in breeding programs, thus increasing the efficiency of breeding programs. The result lines of the RS method from B11742 crossing combination produced plant segregate which has new plant type and resistance to leaf blight disease and better quality of rice [14]. Newest reported by [15] that the effect of recurrent selection on drought tolerance also identified potential lines with high yield and drought tolerance for subsequent varietal development for limited water areas in Breat Wheat.

This research aims to study genetic diversity and agronomic character of F3 lines population using RS method for selection purpose of the next generation population.

\section{MATERIALS AND METHODS}

The research was conducted at Experimental Station, Indonesian Center for Rice Research, Muara Bogor, West Java and at Pondok Kelapa district, Bengkulu, Indonesia. The base population materials are 12 numbers of F2 RS from local Bengkulu upland rice varieties hybrid (Bugis and Sriwijaya) wich it has blast resistance and IR7858-1 and IR148 + lines wich it has drought tolerant.

The experimental design used Augmented Design according to [16]. The average of the adjusted genotypes was obtained after calculated the effect of the block with the formula:

$$
\begin{aligned}
& \qquad P j=B j-M \\
& \text { The adjusted average value }=Y i-P j \\
& =\text { effect blocks all } \mathrm{j} \\
& \mathrm{Bj}=\text { average control in one block } \mathrm{j} \\
& \mathrm{M}=\text { average common control } \\
& \mathrm{Yi}=\text { the value of the } \mathrm{i} \text {-th observation genotype }
\end{aligned}
$$

where: $P \mathrm{j}=$ effect blocks all $\mathrm{j}$

Plots measuring $6 \mathrm{~m}$ x $5 \mathrm{~m}$ consists of $12 \mathrm{~F} 1$ lines. Each line planted two rows of each row contained 12 holes planting and planted two seeds per hole. Each plot planted four lines and four elders as checks. There is five plots experiment as a block for the 20 lines tested. Fourth elders planted in all plots. Spacing $20 \mathrm{~cm} \times 30 \mathrm{~cm}$, and the distance between lines of $40 \mathrm{~cm}$. Fertilization is done with $200 \mathrm{~kg}$ Urea, $100 \mathrm{~kg} \mathrm{SP36}$ and $100 \mathrm{~kg} \mathrm{KCl}$ per hectare. The whole SP36 and $\mathrm{KCl}$ gave at the time of planting, Urea given three times, each third dose at planting, 4 weeks and 7 weeks after planting. control of pests, diseases, and weeds are done in accordance with the needs.
Populations were observed for their performance in agronomic characters. Some populations that are showing good segregations in plant type were selected to be used as base populations. Selected plants among the populations that are having good agronomic characters were selected crossed to each other as shown in Fig. 1. This procedure was repeatedly done until the populations having plants with desired characters to be selected. The selection method is individually. The selected plants then planted and evaluated at pedigree nurseries for performance agronomic characters, such as plant vigor, plant height, the number of tillers, flowering and maturity, a length of panicle, the number of filled grains per panicle, the number of unfilled grains, and weight of grains per hill.

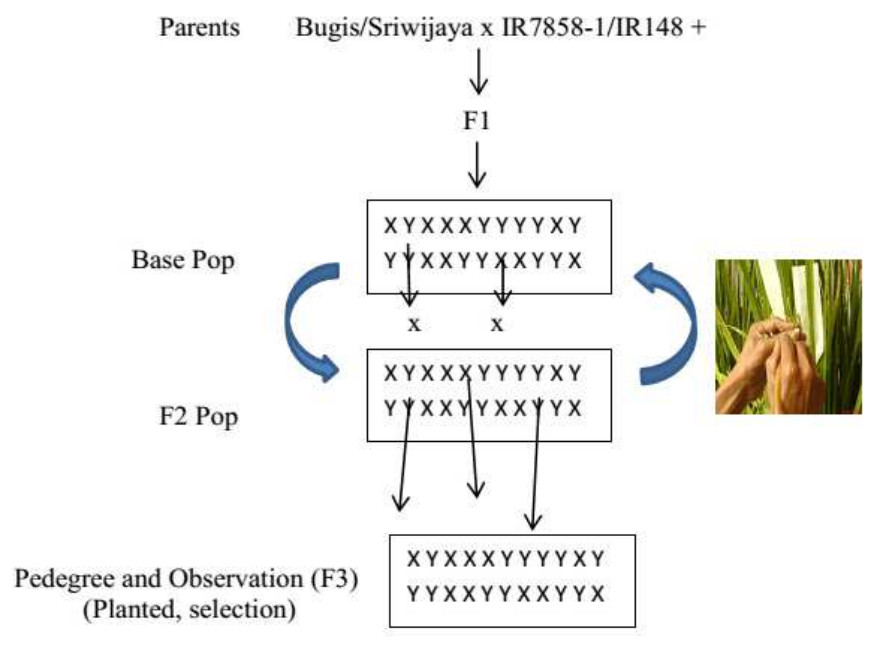

Fig. 1 Recurrent selection (RS)

Genetic variability was estimated from $(\sigma 2 \mathrm{~g})$ and standard deviation of $\sigma \sigma 2 \mathrm{~g}$. A character is considered to have a wide genetical variability if $\sigma 2 \mathrm{~g}>2 \sigma \sigma 2 \mathrm{~g}$ [17]. Criteria of genotypes variability coefficient $(\mathrm{GVC})$ and phenotypic variability coefficient (PVC) is relatively low $(0<\mathrm{x}<25 \%)$, rather lower ( $25 \%<\mathrm{x}<50 \%)$, quite high $(50 \%<\mathrm{x}<$ $75 \%)$, and high $(75 \%<x<100 \%)$ [18]. Heritability values (h2bs) were classified according methods developed by [19]: high $(0.50<\mathrm{h} 2 \mathrm{bs}<1.00)$; medium $(0.20<\mathrm{h} 2 \mathrm{bs}<0.50)$; and low $(\mathrm{h} 2 \mathrm{bs}<0.20)$. Lines were grouped based on plant height, the number of productive tillers character, and maturity. Scorings on agronomical characters used Standard Evaluation System (SES) for rice developed by International Rice Research Institute [20].

\section{RESULTS AND DISCUSSION}

\section{A. Evaluation of Genetic Diversity}

This research resulted in 180 numbers F3 lines selected from recurrent selection (RS). The next evaluation, selection lines in Bengkulu specific locations, to get adapted specific lines generation in the previous growing season. Results of analysis of variance showed that there were significant differences in all characters were observed (Table 1). Genetic diversity can be estimated from genetic diversity $(\sigma 2 \mathrm{~g})$ and the standard deviation of the genetic diversity $(\sigma \sigma 2 \mathrm{~g})$. A character has a wide genetic diversity if $\sigma 2 \mathrm{~g}>2 \sigma \sigma 2 \mathrm{~g}$. The value of plant genetic parameter 
estimation showed that the character of flowering, maturity, plant height, productive tiller, panicle length, the number of filled grains/panicle, the number of unfilled grains/panicle and weight of grains/hill has a wide genetic diversity (Table $1)$.

Criteria of genotypes variability coefficient (GVC) and phenotypic variability coefficient (PVC) is relatively low (0 $<\mathrm{x}<25 \%)$, rather lower $(25 \%<\mathrm{x}<50 \%)$, quite high $(50 \%<x<75 \%)$, and high $(75 \%<x<100 \%)$ [18]. This show that the criteria GVC and PVC is relatively close to the low $(0<x<0: 31)$, is rather low $(0.31<x<0.63)$, is quite high $(0.63<x<0.93)$, and high $(0.93<x<1: 31)$; PVC is relatively low $(0<x<8.0)$, is rather low $(8.0<x<16.0)$, high enough $(16.0<x<24.0)$, and high $(24.0<x<32.0)$. The coefficient of genotypic diversity (GVC) and phenotype (PVC) for the character panicle length, the number of filled grain/panicle, the number of unfill grains/panicle and grain weight/hill between broad to very broad, and has a high heritability value between 0.83-0.91 (Table 1).

The heritability estimates for the character of the observed range from 0.39 to a number of tillers and 0.91 for panicle length. Base on the criteria [19]: $0.50<\mathrm{h} 2 \mathrm{bs}<1.00=$ high; $0.20<\mathrm{h} 2 \mathrm{bs}<0.50=$ medium; h2bs $<0.20=$ low, characters of plant height, flowering and maturity, panicle length, number of fill grains per panicle and grain weight/hill in this study has high heritability (h2bs). Reported by ([5],[21]) that the selection of the character i.e. number of productive tillers, the number of filled grain per panicle, and percentage of empty grain was more effective to be selected because they were well correlated to a weight of grain per hill, possessed high heritability values, and have wide genetic variability. It's mean that the characters which have a high heritability values indicate that genetic factors contribute greater than environmental factors so that the selection of these characters begin in early generations. Similar observations were reported by [21], [22] showed moderate genotypic and phenotypic coefficient of variation, high heritability in a broad sense, moderate genetic advance and moderate genetic advance in the percentage of mean indicate that the influence of environmental condition low on the expression of genes controlling the characters. In other words, the expression of these traits is mainly due to the genetic constituents rather than environmental influence. The wide genetic variabilities were beneficial for further selection processes.

\section{B. Agronomy Characters of Upland Rice Population Crosses Sriwijaya, Bugis, IR7858-1, and IR148}

\section{1). Growth Component}

Agronomic characters were observed in a population of $\mathrm{RS}$, as well as the parent is presented in Table 2 and Fig. 2. There was a diversity of agronomic characters in all character observed. Plant height of populations derived Bugis/IR7858-1 and Bugis/IR148 were very tall $(>131 \mathrm{~cm})$, as same as Sriwijaya/IR148 ranges between 103-140 cm (Table 3). Plant height derived Bugis/IR7858-1 taller than elders. According to plant height standards developed by [20], the population of lines generated Bugis by RS result is more directed at the parent which is between tall to very tall (Table 3). The Sriwijaya as parental had moderate plant height criteria, and Bugis had a very tall, while IR7858-1 and IR148 had criteria between moderate to tall, indicating that the two parents are not stable and there is still segregation between populations.

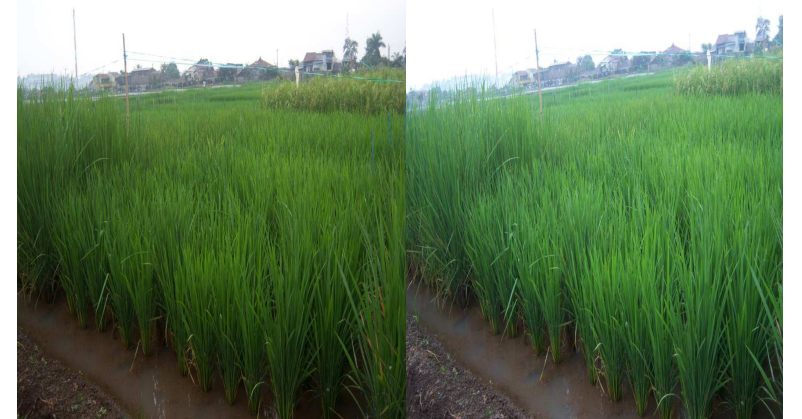

Fig. 2 Performance of agronomic characters of F3 lines selected by Recurrent Selection (RS)

TABLE I

ANALYSIS OF VARIANCES AND GENETIC VARIabILITY OF AgRONOMICAL CHARACTERS OF Rice Line POPUlation DERIVED SRIWIJAYA, BUGIS, IR7858-1, AND IR148

\begin{tabular}{|l|c|c|c|c|c|c|c|c|}
\hline \multicolumn{1}{|c|}{ Characters } & MS & F value & GV & PV & 2xSDGV & $\begin{array}{c}\text { GVC } \\
(\%)\end{array}$ & $\begin{array}{c}\text { PVC } \\
(\%)\end{array}$ & $\mathbf{h}^{2} \mathbf{b s}$ \\
\hline Flowering (dap) & 968.72 & $125.2^{* *}$ & 48.05 & 55.79 & 35.37 & 0.08 & 0.08 & 0.86 \\
\hline Maturity (dap) & 1259.52 & $26.2^{* *}$ & 60.57 & 108.74 & 45.99 & 0.06 & 0.08 & 0.56 \\
\hline Plant Height (cm) & 5885.19 & $64.6^{* *}$ & 289.7 & 380.81 & 214.9 & 0.15 & 0.17 & 0.76 \\
\hline $\begin{array}{l}\text { Number of productive } \\
\text { tiller }\end{array}$ & 227.23 & $13.8^{* *}$ & 10.54 & 27.05 & 8.3 & 0.29 & 0.47 & 0.39 \\
\hline Penicle length (cm) & 2474.78 & $200.6^{* *}$ & 123.12 & 135.46 & 90.37 & 0.73 & 0.76 & 0.91 \\
\hline $\begin{array}{l}\text { Number of filled } \\
\text { grains/panicle }\end{array}$ & 50583 & $1254.6^{* *}$ & 2527.1 & 2567.45 & 1847.03 & 1.31 & 1.32 & 0.98 \\
\hline $\begin{array}{l}\text { Number of unfilled } \\
\text { grains/panicle }\end{array}$ & 1629.44 & $97.3^{* *}$ & 80.63 & 97.38 & 59.5 & 0.66 & 0.72 & 0.83 \\
\hline Grain weight /hill (g) & 1821.88 & $136.68^{* *}$ & 90.43 & 103.76 & 66.53 & 0.66 & 0.71 & 0.87 \\
\hline
\end{tabular}

Note: $M S=$ Mean Square; GV=Genotipic Variability; $P V=$ Phenotypic Variability; SDGV=Standar Deviation of

Genotipic Variability; GVC= Genotipic Variability Coefficient; $P V C=$ Phenotypic Variability

Coefficient; $h 2 b s=$ Heritability; dap=day after planting; $* *$ significant at $\alpha=1 \%$ 
TABLE II

AGRONOMicAl CHARACTERs OF F3 RECURRENT SELECTION FROM PARENT OF SRIWIJAYA, BugIS, IR7858-1, AND IR148

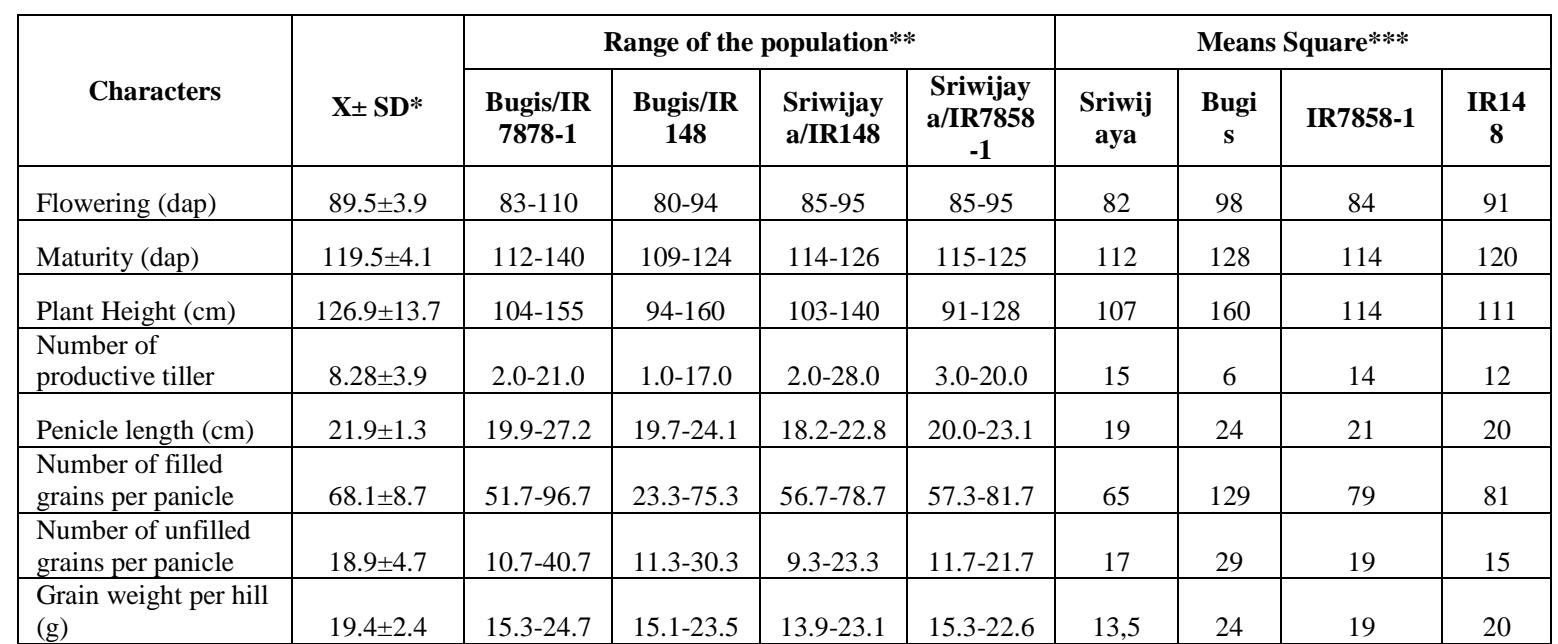

Note: $* \pm S D=$ mean \pm Standar Deviation; **Population F3 range of 37 hill each; ***Population parent of 15 hill each; dap $=$ day after planting

TABLE III

Grouping of THE F3 RS POPULATION BASE ON NUMBER Plant HEIGHT

\begin{tabular}{|l|c|c|c|c|c|}
\hline \multirow{2}{*}{ Population } & \multicolumn{5}{|c|}{ Grouping of plant height } \\
\cline { 2 - 6 } & $\begin{array}{c}\text { short } \\
(<\mathbf{9 0} \mathbf{c m})\end{array}$ & $\begin{array}{c}\text { moderate } \\
(\mathbf{9 1 - 1 1 0} \\
\mathbf{c m})\end{array}$ & $\begin{array}{c}\text { tall } \mathbf{( 1 1 1 -} \\
\mathbf{1 3 0} \mathbf{~ c m})\end{array}$ & $\begin{array}{c}\text { very tall } \\
(>\mathbf{1 3 1} \mathbf{c m})\end{array}$ & Total \\
\hline Bugis/IR7858-1 & 0 & 6 & 38 & 106 & 150 \\
\hline Bugis/IR148 & 0 & 4 & 38 & 98 & 140 \\
\hline Sriwijaya/IR148 & 0 & 24 & 117 & 6 & 147 \\
\hline Sriwijaya/IR7858-1 & 0 & 36 & 71 & 0 & 107 \\
\hline Sriwijya & 0 & 20 & 0 & 0 & 20 \\
\hline Bugis & 0 & 0 & 0 & 20 & 20 \\
\hline IR7858-1 & 0 & 2 & 18 & 0 & 20 \\
\hline IR148 & 0 & 19 & 1 & 0 & 20 \\
\hline
\end{tabular}

Note: Base on IRRI (1996)

TABLE IV

GROUPING OF THE F3 RS POPULATION BASE ON NUMBER OF TILLERS

\begin{tabular}{|l|c|c|c|c|c|}
\hline \multirow{2}{*}{ Population } & \multicolumn{5}{|c|}{ Grouping of number of tillers } \\
\cline { 2 - 6 } & $\begin{array}{c}\text { very } \\
\text { low } \\
(<\mathbf{5})\end{array}$ & $\begin{array}{c}\text { Low } \\
\mathbf{( 5 - 9 )}\end{array}$ & $\begin{array}{c}\text { medium } \\
(\mathbf{1 0 - 1 9 )}\end{array}$ & $\begin{array}{c}\text { high } \\
(>\mathbf{1 9})\end{array}$ & Total \\
\hline Bugis/IR7858-1 & 28 & 62 & 59 & 1 & 150 \\
\hline Bugis/IR148 & 52 & 72 & 16 & 0 & 140 \\
\hline Sriwijaya/IR148 & 10 & 68 & 68 & 1 & 147 \\
\hline Sriwijaya/IR7858-1 & 5 & 45 & 56 & 1 & 107 \\
\hline Sriwijya & 0 & 0 & 20 & 0 & 20 \\
\hline Bugis & 0 & 20 & 0 & 0 & 20 \\
\hline IR7858-1 & 0 & 0 & 20 & 0 & 20 \\
\hline IR148 & 0 & 0 & 20 & 0 & 20 \\
\hline
\end{tabular}

Note: Base on IRRI (1996)

TABLE V

GROUPING OF THE F3 RS POPULATION BASE ON MATURITIES

\begin{tabular}{|l|c|c|c|c|c|}
\hline \multirow{2}{*}{ Population } & \multicolumn{5}{|c|}{ Grouping of maturity } \\
\cline { 2 - 6 } & $\begin{array}{c}\text { earlier } \\
(<\mathbf{1 1 5} \\
\text { dap) }\end{array}$ & $\begin{array}{c}\text { medium } \\
\mathbf{( 1 1 5 - 1 2 5} \\
\text { dap) }\end{array}$ & $\begin{array}{c}\text { late } \\
(\mathbf{1 2 6 - 1 5 0} \\
\text { dap) }\end{array}$ & $\begin{array}{c}\text { extremely } \\
\text { late (>151 } \\
\text { dap) }\end{array}$ & Total \\
\hline Bugis/IR7858-1 & 8 & 108 & 34 & 0 & 150 \\
\hline Bugis/IR148 & 23 & 117 & 0 & 0 & 140 \\
\hline Sriwijaya/IR148 & 2 & 144 & 1 & 0 & 147 \\
\hline Sriwijaya/IR7858-1 & 0 & 107 & 0 & 0 & 107 \\
\hline Sriwijya & 20 & 0 & 0 & 0 & 20 \\
\hline Bugis & 0 & 0 & 20 & 0 & 20 \\
\hline IR7858-1 & 18 & 2 & 0 & 0 & 20 \\
\hline IR148 & 2 & 18 & 0 & 0 & 20 \\
\hline
\end{tabular}

Note: Base on IRRI (1996) 
The frequency of distribution of the F3 population leads to be moderate to very tall criteria (Table 3). Based on grouping the number of tillers [20], the number of productive tillers in Bugis/IR7858-1 ranged from 2.0-21.0, whereas Bugis/IR148 had 1.0-17.0 (Table 4). Therefore, population of lines derived Bugis/IR7858-1 more dominant being moderate to high, and can be grouped into 62 medium productivity lines (10-19) and 59 high productivity lines (> 19), whereas those 140 genotypes derived from Bugis/IR148 had 52 very low productivity lines $(<5)$ and two had low productivity lines (5-9) (Table 4).

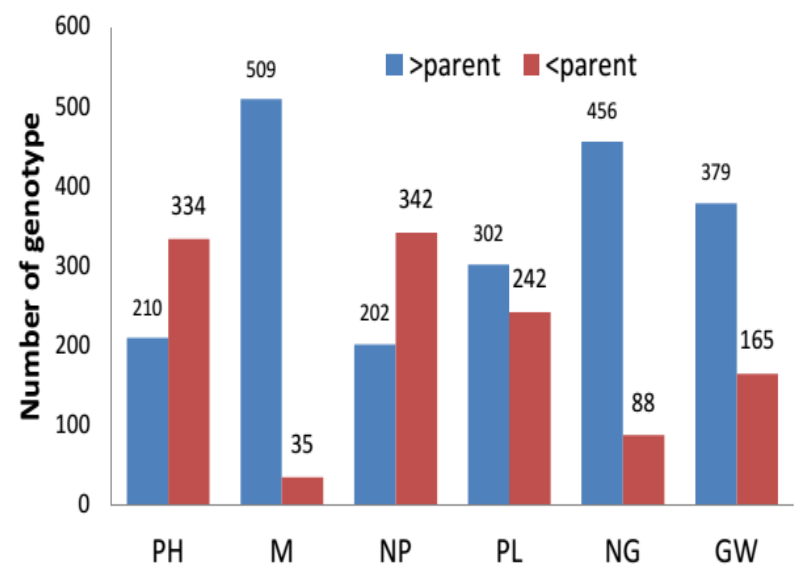

Fig. 3 The frequency distributions of the six agronomic traits,i.e. $\mathrm{PH}$ (plant height), M(maturity), NP(the number of productive tillers),PL(panicle length), NG(the number of filled grains per panicle), GW (grain weight per hill)

The number of productive tillers in genotype results of crossing Sriwijaya/IR148 and Sriwijaya/IR7858-1 more dominant in low to medium productivity lines (Table 4). The frequency distribution of the parental population tends to be low to medium productivity lines (Table 2).

Flowering in the genotype result of all crosses more dominant in the medium lines (115-125 days after planting), this shows that there is still segregation occurs in genotypes populations (Table 2). The frequency distribution of the Sriwijaya parental more directed at early maturity group, while Bugis is more directed at the late age groups. Therefore, both IR148 and IR7858-1 parental more lead to be the early maturity group to medium. This shows that the two parents still segregating (Table 5). Reference [6] stated that the development of very early maturity and high yield line in relatively shorter time through recurrent selection proved that this method was more efficient and promising in rice improvement.

A broad range of segregation was seen in the progeny of the elite hybrids studied in F3 generation. The range of segregation of six important agronomic traits, i.e. plant height, maturity, the number of productive tillers, panicle length, the number of filled grains, and grain weight per hill are represented in Fig. 3. The frequency distributions of the six agronomic traits for F3 RS revealed the uniform distribution of genotypes with some values on the higher side of the parent and some on the lower side. This shows that there were still segregating between genotype. Recurrent selection (RS) is a method of plant selection and crossing from systematic population to develop new superior population [7], [8]-[10]. On the other hand, this method is a powerful procedure to accumulate desirable genes from crossing recombination between continuously selected segregants to get the best new population than before, because it consists of plants that have a combination of traits is desired. The sixty-one percentage lines had shorter plant height than parents. For maturity, 93 percent had higher leads to elders. The distribution of the number of productive tillers, panicle length, the number of filled grains, and grain weight per hill were 55, 37, 83, and 69 percent respectively more than parent. Wide diversity will more benefit for the next selection process.

Overall, the analysis of variance for the agronomic performance of F3 lines from revealed significant differences in all characters was observed (Table 1). Populations have high genetic diversity will give a good response to selection for high genetic diversity will provide great opportunities to get the right cross combination with the superior combined properties. Reported by [4], [5] that it is important to achieve the purpose of the selection so that the selection of one or more characters can be made more effective, should be known relationships between agronomic characters, yield and yield components.

\section{Yields Component}

The average of panicle length was $21.99 \mathrm{~cm}$ with a standard deviation of 1.3. Bugis had $24 \mathrm{~cm}$ of panicles length range, so its derivatives on cross Bugis/IR7858-1 and Bugis/IR148 had a range of higher panicle length compared Sriwijaya (Table 2). Generally, long panicles produced more grain than short panicles. However, density grain was more important role than the panicle length, in affecting productivity.

The average number of fill grains/panicle was 68.04 and 8.67 of SD. The derivative crosses Bugis/IR7858-1, Sriwijya/IR148 and Sriwijya/IR7858-1 had higher potential average fill grains than the Bugis/IR148. Lines derived from Bugis/IR7858-1 had the most filled grain i.e. 96.67 grains, while Bugis/IR148 had the least. There was quite a large variability in the standard deviation of total grains and the number of filled grain per panicle between lines (Table 2). Limited sink to source, or earlier senescence might have been the cause of the large percentage of empty grains. Reference [23] reported that at the end of the filling period, or during the aging period, activities of Ribulose bisphosphate carboxylase activase and Rubisco binding protein alpha subunit that regulate photosynthate accumulation during the filling period were reduced.

The number of unfilled grains/panicle result of cross Bugis higher than that more. Low fertility due to the void that is high enough on the elders constituent namely Bugis (29 grains/panicle) which resulted in some derivative lines has a fairly high emptiness.

Average grain weight per hill is $19.43 \mathrm{~g}$ with SD 1.36. Lines derived Bugis/IR7858-1 had the most grain weight/hill (24.70 g), whereas Sriwijaya/IR7858-1 had $26.50 \mathrm{~g}$. These values were higher than those from their parental lines, i.e. $24 \mathrm{~g}$ in Bugis and $19 \mathrm{~g}$ in Sriwijaya (Table 2). In general, there had been an increase in the average value of the all the characters were observed. Recurrent Selection (RS) have a greater chance produce superior lines expected because elite population having good properties result from crosses 
between selected plant is kept constant. Reference [12] showed that recurrent selection applied to genetically divergent populations in the first and second cycles were significant and produced high yield $(369.9 \mathrm{~kg} / \mathrm{ha}(6.65 \%)$ and $259.9 \mathrm{~kg} / \mathrm{ha}(4.67 \%)$, respectively). Reported by [8] used a combination of recurrent selection and anther culture in a breeding program to accelerate the formation of new type lines, so it can improve the efficiency of breeding programs. RS lines result of the combination segregate cross B11742 produce plants that have the nature of new type rice and HDB resistance and better quality rice [14]. All agronomic characters were observed in populations F3 RS plants varied, in some of which are similar to one parent, there are intermediates, and there were exceed two parents. A high diversity is highly advantageous for the stage the next selection. Expected in the next generation will appear genotypes superior caused by segregation in the population as material selection, and will be obtained superior lines as previously intended.

\section{CONCLUSIONS}

The recurrent selection had been implemented in local varieties to produce drought tolerance and blast resistance rice lines. A number of $\mathrm{F} 2 \mathrm{RS}$ line used as based population and F3 populations had been identified. The potential for agronomic characters had produced some selected lines. There was an increase in the value of the average number of filled grains/panicle and grain fertility compared with its constituent elders.

Selection based on plant height, the number of productive tillers, the number of grains per panicle, the number of filled grain per panicle and grain weight/hill will be effective in early generations because it had high heritability values and broad genetic diversities. Further evaluation of lines should be arranged on the specific environment in order to obtain superior lines as previously intended.

\section{ACKNOWLEDGMENT}

The author would like to thank the Directorate General of Higher Education, Ministry of Education and Culture, through Competitive Grants by DIPA UNIB Number. 0824/023-04.2.16/08/2011 on 9th December 2011, based contract Number: 130/H.30.10/UN30.10/PL/2012 on 02nd March 2012.

\section{REFERENCES}

[1] T. Sitaresmi, R.H. Wening, A.T. Rakhmi, N. Yunani, dan U. Susanto. "Pemanfaatan plasma nutfah padi varietas lokal dalam perakitan varietas unggul". Iptek Tanaman Pangan 8(1):22-30. 2013.

[2] H. Alfi, B. Warman, I. Suliansyah, E. Swasti, and Sobrizal. "Genetic improvement in west sumatera landraces to get the early maturing mutants by induced mutations". IJASEIT 5(5):275-279. 2015 .
[3] I. Dwipa, I. Suliasyah, A. Syarif,, and E. Swasti. "Exploration and Characterization of Brown Rice Germplasms in West Sumatra". IJASEIT 4(3):34-37. 2014.

[4] Zen, S. "Parameter genetik karakter agronomi galur harapan padi sawah”. Stigma 10(4):325-330. 2002.

[5] R. Herawati, B.S. Purwoko, and I.S. Dewi. "Characterization of Doubled Haploid Derived from AntherCulture for New Type Upland Rice”. J. Agron. Indonesia 38(3) : 170 - 176 . 2010.

[6] B. Abdullah. "Progress of rice improvement through recurrent selection”. J. Agron. Indonesia 37(3): 188 - 193 . 2009.

[7] WR. Fehr. Principles of Cultivar Development. Volume 1. Theory and Technique. McGraw-Hill, Inc. New York, St. Louis, San Fansisco. Vol 1. 1987.

[8] B. Abdullah, I.S. Dewi, Sularjo, H. Safitri, A.P. Lestari. " Perakitan padi tipe baru melalui seleksi silang berulang dan kultur anter". Penelitian Pertanian Tanaman Pangan 27(1):1-8. 2008

[9] A.P.C.G. Berilli, M.G. Pereira, R.D.S. Trindade, F.R.D. Costa, and K.S.D. Cunha. "Response to the selection in the 11th cycle of reciprocal recurrent selection among full-sib families of maize". Acta Scientiarum, Agronomy 35: 435-441. 2013.

[10] O.P.Morais Júnior., P.G.S. Melo, O.P. Morais, O.P. Castro, F. Breseghello, M.M. Utumi, J.A. Pereira, F.J. Wruck, and J.M.C. Filho. "Genetic progress after cycles of upland rice recurrent selection". Sci. Agric. 72(4):297-305.2015.

[11] N. Niu, V.N. Arief, I.H. DeLacy, D. Lush, J. Sheppard, G. Zhang, and M.J. Dieters. "Genetic gain in yield and protein over two cycles of a wheat recurrent selection Program”. Breeding Science 60: 181186. 2010.

[12] Rangel, P.H.N., O.P. Morais and F.J.P. Zimmermann. "Grain yield gains in three recurrent selection cycles in the CNAIRAT 4 irrigated rice population". Crop Breeding and Applied Biotechnology, 2(3):369-374. 2002

[13] G.S.Silva, M.A.P. Ramalho, Â.F.B. Abreu, and J.A.R. Nunes. "Estimation of genetic progress after eight cycles of recurrent selection for common bean grain yield". Crop Breed. Appl. Biotechnol. 10(4):351-356. 2010.

[14] B. Abdullah dan Sularjo. 2008. Seleksi silang berulang (SSB) untuk membentuk padi tipe baru. Seminar Nasional Padi, BBPTPSukamandi. 2008.

[15] P. Ramya, G.P. Singh, N. Jain, P.M. Singh, M.K Pandey, K. Sharma, A. Kumar, Harikrishna, and K.V. Prabhu. "Effect of recurrent selection on drought tolerance and related morpho-physiological traits in bread wheat". PlosOne (DOI:10.1371/journal.pone.0156869) 11(6):1-17. 2016.

[16] A. Baihaki. Teknik Rancang dan Analisis Penelitian Pemuliaan. Fakultas Pertanian, Universitas Padjadjaran, Bandung. 91 hal. 2000.

[17] A. Pinaria, A. Baihaki, R. Setiamihardja, A.A. Daradjat.. "Variabilitas genetik dan heritabilitas karakter-karakter biomassa 53 genotipe kedelai”. Zuriat 6:88-92. 1995.

[18] Moedjiono dan M.J. Mejaya. "Variabilitas genetik beberapa karakter plasmanutfah jagung koleksi Balittas Malang". Zuriat 5(2):2732.1994 .

[19] W.D. Stanfield WD. Theory and Problems of Genetics. 2nd edition. Schain.s Outline Series. Mc.Graw Hill Book Co. New Delhi. 1983.

[20] IRRI. Standard evaluation system for rice International rice testing program. The International Rice Testing Program (IRTP) IRRI Los Banos, Philippines. 1996.

[21] A.K. Konate1, A. Zongo, H. Kam, A. Sanni, and A. Audebert. "Genetic variability and correlation analysis of rice (Oryza sativa L.) inbred lines based on agromorphological traits". African Journal of Agricultural Research. 11(35):3340-3346. 2016.

[22] M.F.K. Mishu, M.W. Rahman, M.A.K. Azad, B.K. Biswas, M.A.I. Talukder, M.O. Kayess, M.R. Islam, and M.R. Alam. "Study on Genetic Variability and Character Association of Aromatic Rice (Oryza sativa L.) Cultivars. International Journal of Plant \& Soil Science 9(1): 1-8. 2016

[23] Z.W. Li, J. Xiong, Z. F. Li, X. H. Qi, H. F. Chen, C. H. Shao.. "Analysis of differential expression of proteins in rice leaf sheath during grain filling”. Acta Agronomica Sinica 34:619-626. 2008. 